УДК 323:504 (477)

https://doi.org/10.34142/24130060.2020.20.1.10

\title{
ІНТЕГРАЦІЯ ЕКОЛОГІЧНОГО ПИТАННЯ В УКРАЇНСЬКИЙ ПОЛІТИЧНИЙ ПРОСТІР: ПРОБЛЕМНІ АСПЕКТИ
}

\author{
Ю. І. Калюжна \\ Харківський національний педагогічний університет імені Г.С. Сковороди
}

В статті здійснено спробу визначити ключові суспільно-політичні детермінанти, які перешкоджають інтеграчії екологічного питання в політичний простір сучасної Украйни: 1) низький рівень політичної компетентності лідерів «екопартій», внутріпартійна боротьба, нездатність до політичних альянсів $і$ компромісів з крупними політичними гравцями та відверті спекуляиії на екологічній тематиці, - все це призвело до того, щчо партії «зелених» були дискредитовані в очах українських вибориів; 2) декларативно-формалізоване ставлення політиків до екологічної проблематики, здебільшого у передвиборчих програмах украӥнських політичних партій екологічні аспекти відображено популістично, формально та декларативно, а екологічне законодавство та механізми його реалізаџії є недосконалими $і$ на практиці не вирімують екологічних проблем; 3) екологічний патерналізм украйнців, попри визнання пріоритетності екологічного питання та усвідомлення особистої відповідальності за екологічне майбутнє, украӥнцям притаманний патерналістський підхід - прагнення перекладати відповідальності за вирішення екологічні проблеми на владу, індекси довіри до якої критично низькі; 4) «рутинізачія державної кризи», трансформачійні прочеси украӥнського демократичного державотворення, щзо супроводжуються системними кризами в політичній, економічній та соціальній сферах-призвели до того, щцо екологічне питання було витіснене на периферію політичного життя. Констатовано, влада повинна дивитися на всі інші сфери життя крізь призму екологічної політики, а відповідальність за екологічне майбутнє Украйни є двостороннім обов'язком - політиків $i$ вибориів, зволікання ж з вирішенням екологічних проблем неминуче призведе до маситабної «екологічної кризи».

Ключові слова: екологічний рух, екологічні проблеми, екологічна криза, екологічна політика, екопартії та партії «зелених», виборчий прочес, екологічна компетентність, екологічний патерналізм.

\section{ИНТЕГРАЦИЯ ЭКОЛОГИЧЕСКОГО ВОПРОСА В УКРАИНСКОЕПОЛИТИЧЕСКОЕ ПРОСТРАНСТВО: ПРОБЛЕМНЫЕАСПЕКТЫ}

\section{Ю. И. Калюжная}

В статье осуществляется попытка определить ключевые общественнополитические детерминанты, которые препятствуют интеграции экологического вопроса в политическое пространство современной Украины: 1) низкий уровень политической компетентности лидеров «экопартий», внутрипартийная борьба, неспособность к политическим альянсам и компромиссам с крупными политическими игроками, а так же откровенные спекуляции на экологической тематике дискредитировали партии «зеленьх» в глазах украинских избирателей; 2) декларативно-

(C) Ю.І. Калюжна, 2020 
формализованное отношение политиков $\kappa$ экологической проблематике, преимущественно в предвыборных программах украинских политических партий экологические аспекты представлены популистично, формально и декларативно, а экологическое законодательство и механизмы его реализации являются не совершенными и на практики не решают экологических проблем; 3) экологический патернализм украинцев, несмотря на признание приоритетности экологического вопроса и осознание личной ответственности за экологическое будущее, украинцам свойственен патерналистский подход, стремление переложить ответственность за решение экологических проблем на власть, индексы доверия которой критично низкие; 4) "рутинизация государственного кризиса», трансформачионные процессы украинского демократического построения государства, которые сопровождались системными кризисами в политике, экономике и сочиальной сферах - привели к тому, что экологический вопрос был вытеснен на периферию политической жизни. Констатировано, что власть должна рассматривать все сферы общественной жизни через призму экологической политики, а ответственность за экологическое будущее Украины является двусторонней обязанностью политиков и избирателей, промедление с решением экологических проблем неизбежно приведёт к масштабному «экологическому кризису».

Ключевые слова: экологическое движение, экологические проблемы, экологический кризис, экологическая политика, экопартии и партии «зеленых», избирательный процесс, экологическая компетентность, экологический патернализм.

\section{NTEGRATION OF ENVIRONMENTAL ISSUES INTO UKRAINIAN POLITICAL SPACE: ASPECTS OF THE PROBLEM}

\section{J. Kalyuzhna}

The article attempts to identify the key socio-political determinants which prevent the integration of the environmental issue into the political space of modern Ukraine. They are: 1) low level of political competence of «eco-parties» leaders, internal party struggle, inability to create political alliance sand compromises with major political players and speculating on environmental issues. All these reasons led to the Green Party being discredited in the opinion of Ukrainian voters; 2) declarative-formalized attitude of politicians to environmental issues, mostly in the election programs of Ukrainian political parties, environmental aspects are formally mentioned, in populist and declarative ways, and environmental legislation and mechanisms for its implementation are imperfect and in reality do not solve environmental problems; 3) environmental paternalism of Ukrainians, despite the recognition of the priority of the environmental issue and the awareness of personal responsibility for the ecological future, the Ukrainian shave a paternalistic attitude and desire to redirect the responsibility for solving environmental problems to Power, whose confidence index is critically low; 4) the "routinization of the state crisis», the transformative processes of the Ukrainian democratic state formation, with systemic crises in the political, economic and social fields led to the ecological issue being pushed from the centre of political life. The article emphasizes that responsibility for Ukraine's environmental future is a two-sided responsibility, both of politicians and voters, and the delay of environmental problems resolution will inevitably lead to a large-scale «environmental crisis».

To sum up, «The world is changing, and environment protection, climate change prevention, a sustainable economy must become the lens through which the authorities must look at all other sides of life» (Minister of Ecology and Natural Resources of Ukraine O. Semerak, 2018), we hope this will become a political imperative for Ukraine's environmental policy and, therefore, a guarantee for Ukraine's environmental future. 
Key words: environmental movement, environmental problems, environmental crisis, environmental policy, eco-parties and green parties, electoral process, environmental competence, environmental paternalism.

Постановка проблеми. Напередодні парламентських виборів 2019 року коаліція неурядових громадських організацій, які опікуються проблемами довкілля, звернулась з закликом до всіх політичних партії та кандидатів у народні депутати передбачити вирішення екологічних проблем та надати відповіді на наступні критично важливі питання: 1) невідповідність цілям сталого розвитку - українська економіка $є$ найбільш енергоємною у світі; 2) зриви строків імплементації природоохоронної частини Угоди про асоціацію з СС - більше половини завдань напрямку «навколишнє середовище» не прийняті, або прийняті з суттєвими порушенням строків; 3) споживацьке ставлення до природних ресурсів - в Україні діють та збільшуються неоголошені монополії, а хижацьке відношення до природних ресурсів підтримується на державному рівні; 4) деструктивність природоохоронних контролюючих органів - неефективність екологічної інспекції сприяє екологічному правовому нігілізму, що визнано навіть на державному рівні; 5) Неефективна дозвільна система - видача дозволів та ліцензій на забруднення довкілля перетворилася на прибутковий бізнес для чиновників всіх рівнів; 6) неефективне використання екологічного податку великі промислові гравці вже не перший рік лобіюють ідею повернення екоподатків забруднювачам, використовуючи аргумент неефективності використання цих коштів розпорядниками. Та у підсумку, експертамиекологами було надано критично незадовільну оцінку, щодо стану екологічної політики в сучасній Україні - «за роки незалежності не створена система контролю та моніторингу за станом навколишнього природного середовища, недостатня судова практика щуодо захисту довкілля, відсутність міжвідомчої взаємодї між Мінприроди, МОЗ та Міносвіти, відсутність системної та багаторівневої екологічної просвіти, призвели до основних проблем забруднення довкілля України та погірмення суспільного здоров'я» (Koalitsiia neuriadovykh hromadskykh orhanizatsii, 2019). 
Аналіз актуальних досліджень. Теоретичний аналіз екологічних аспектів державної політики в Україні представлено в роботах -
М. Алексієвець,
О. Андрєєв,
В. Андронов,
Н. Андрусевич,
О. Білорус,

О. Варго, О. Васюта, Т. Галушкіна, Т. Гардащук, О. Гарнець, М. Гладкий, Н. Гозак, А. Голіков, О. Горин, Г. Гошовська, М. Грановська, О. Дацій, I. Дедю, Г. Дзяна, А. Дєгтяр, О. Дзюбенко, С. Домбровська, І. Жданова, О. Задубрівська, М. Згуровський, К. Карпенко, В. Керецман, М. Кисельов, В. Ковальчук, В. Крисаченко, Л. Курняк, О. Куценко, О. Лазор, В. Лісничий, А. Льовочкіна, В. Лук'янихіна, О. Момотова, Г. Мороз, В. Недурак, Н. Нижник, О. Осауленко, О. Перова, В. Рехкал, С. Романюк, С. Рудишин, К. Рудницка, Н. Усенко, О. Салтовський, А. Самодрин, Л. Сергієнко,

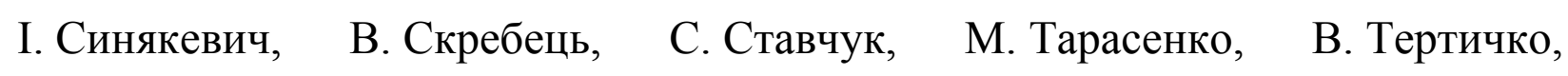
Н. Томенко, Т. Туница, А. Урсула, А. Шумілова, Л. Юрченко, С. Яковенко, Я. Яценко та багатьох інших науковців.

Відтак, мета статті - полягає у спробі визначити ключові суспільнополітичні детермінанти, що перешкоджають інтеграції екологічного питання в український політичний простір.

Виклад основного матеріалу. Екологічний рух, який сформувався у другій половині ХX століття, з вуличних протестів проти ядерного озброєння та «народного голосу» за право жити в «екологічно безпечному світі», - у Канаді, Німеччині, Великобританії, Франції, Італії, Нідерландах, Австрії, Фінляндії, Бельгії, Австралії, Новій Зеландії та багатьох інших країнах західного світу, - через декілька десятиліть набув форм політичних сил загальнонаціонального масштабу, так політичні партії,- «Зелена Партія Канади» (Канада), «Спілка 90/Зелені» (Німеччина), «Свропа Екологія Зелені» (Франція), «Зелені Ліві» (Нідерланди), «Зелена Альтернатива» (Австрія), «Зелена Спілка» (Фінляндія), «Австралійська Партія Зелених» (Австралія) та інші - міцно закріпили свої парламентські та урядові позиції. Фактично, в західній політичній практиці «імплементація екологічного руху» у «велику політику» відбувалась еволюційним шляхом,- це був рух «знизу вверх», - від 
масових соціальних протестів екологічно свідомих громадян до створення «зелених» політичних партій, із міцною ідеологічною платформою на основі екологічних цінностей та імперативів екологічного майбутнього. Досліджуючи історію становлення екопартій А. Толстоухов, звертає увагу: «частина 3 тих, хто очолює сьогодні зелені партії, були активними учасниками вуличних виступів», та додає «зростання екологічних організацій політичного спрямування пояснювалося передусім тим, що саме «зеленим» легше за все було перекинути місток між «високою» політикою й турботами звичайних людей» (Tolstoukhov, 2006).

В Україні, за визначенням дослідника С. Люленко, екологічний рух пройшов 3 основних етапи становлення:

1) 1960 - перша половина 1980 років: екологічна проблематика перебувала у полі зору окремих груп екоактивістів, які діяли переважно на місцевих рівнях;

2) 1986-1990 роки (активна фаза): Чорнобильська катастрофа 1986 року стала каталізатором підйому громадсько-екологічного рух в Україні, створюються різноманітні масові екологічні організації, поширюється правдива інформація про стан довкілля, значно посилюється політизація екологічного руху, відбуваються численні мітинги та демонстрації, на яких екологічні гасла доповнюються політичними, поширюється практика блокування екологічно шкідливих об’єктів тощо- відбувається створення першої національної неурядової екологічної організації «Зелений світ» (1987);

3) 31991 року і до сьогодні: після проголошення Незалежності у 1991 році одним із перших законодавчих актів Верховної Раді став Закон України «Про охорону навколишнього природного середовища», в якому було проголошено нову стратегію природокористування та здійснення контролю над забезпеченням екологічного суверенітету. Зусиллями активістів екологічного руху було запроваджено мораторій на спорудження 
нових АЕС та посилено тиск на владу 3 вимогами, щодо вдосконалення правового регулювання питань охорони природи (Liulenko, 2017, s. 64).

Здавалось, логічним продовження еволюційного шляху українського громадсько-екологічного руху мав би бути пошук ефективного інструментарію та дієвих механізмів, для вирішення екологічних проблем регіонального та всеукраїнського характеру, зокрема, - створення «зелених» політичних партій та включення їх в політичну боротьбу, адже «Рух зелених в Україні був не лише суто екологічним, до того ж він був вагомою складовою бурхливого суспільно-політичного життя кінця 1980 - початку 1990-х рр., а природоохоронні акції сприймалися як важливі суспільно значущі пріоритети» (Liulenko, 2017, s. 64-65), - втім, попри те, що в українському політичному просторі з'являються політичні партій екологічної спрямованості, вони у виборчих перегонах традиційно залишаються на позиціях «політичних -аутсайдерів» (за виключенням, 1998 року, коли «Партія Зелених України» отримала 5,4\% голосів виборців, що дорівнювало 19 депутатським мандатам) (Datatowel.in.ua, 2019). Парадоксально, але попри очевидне погіршення екологічної ситуації в Україні, про що звітують українські та міжнародні екологічні організації, політичні партії «зеленого спектру» не отримують підтримки виборців та навіть втрачають здобуті політичні позиції, що негативно позначається на перспективах політичного та законодавчого вирішення екологічних проблем, відтак, - спробуємо визначити ключові суспільно-політичні детермінанти, які перешкоджають інтеграції екологічного питання в український політичний простір.

По-перше, низький рівень політичної компетентності лідерів «екопартій», певною мірою, відповідальність за втрату політичної популярності, яку мали «зелені» за часів піднесення громадсько-екологічного руху можна покласти саме на лідерів цих партій, адже внутріпартійна боротьба, нездатність до політичних альянсів і компромісів 3 крупними політичними гравцями, а згодом й відверті спекуляції на екологічній тематиці - призвели до дискредитації «зелених» партій в очах українських 
виборців. В означеному контексті, ілюстративними є приклади, які наводить дослідник А. Толстоухов: «Першою політичною перемогою ПЗУ (Партія Зелених України) стали парламентські вибори 1998 року. Але на виборах у 2002 році ПЗУ не подолала 4-процентний бар’єр. Однією з причин поразки було клонування зелених партій: депутати Орест Мельников та Михайло Гуцол, які вийшли з фракції ПЗУ, ініціювали процес створення нових партій зеленого спектра. М. Гуцол створив спочатку екологічну партію «Захист», а згодом - політичний блок «Райдуга», що послуговувалися екологічними гаслами. О. Мельников створив під себе «Зелену партію XXI» (Tolstoukhov, 2006), та наводить приклад політичного прагматизму західних «зелених»: «німецька партія зелених (НПЗ), яка у 1983 році отримала 1 млн. голосів виборців, що дозволило політикам-екологам пройти в бундестаг. В 1998 році (НПЗ) потрапила до федерального уряду із Соціал-демократичною партією Німеччини у червоно-зеленому альянсі, а один із активістів партії Йошка Фішер одержав посаду віце-канцлера» (Tolstoukhov, 2006), таким чином, продемонструвавши здатність західних «зелених» партій до складних політичних угод та рішучих дії у боротьбі за вирішення екологічних питань. Що ж до, політичних спекуляцій то, тут важко не погодитись 3 думкою політичного консультанта Р. Бортніка, який висловив припущення, що на парламентських виборах 2019 року, українські політики будуть знову намагатись експлуатувати екологічне питання і у боротьбі 3 електоральні симпатії апелюватимуть до регіональних екологічних проблем: «активність політиків по відношенню до екологічних питань слід очікувати на сході та півдні України, де ще збереглись промислові підприємства, в так званому «іржавому поясі України». У таких містах, як Маріуполь, Жовті Води, Червоноград, Дніпро. У цих містах проблема екології в свідомості громадян стоїть дуже гостро. ...» (Bortnik, 2019), варто зазначити, відбувається чергова або позачергова зміна виборчих циклів, проте, - реальних кроків до вирішення локальних та національних екологічних проблем 3 боку українських політиків - не має. 
По-друге, декларативно-формалізоване ставлення політиків до екологічної проблематики, так, за висновками експертів, здебільшого у передвиборчих програмах українських політичних партій екологічні аспекти відображено формально i фрагментарно 3 мінімальними згадками декларативно-популістського характеру, на кшталт, «збереження природи», «оздоровлення довкілля», «вирішення екологічних питань», «виведення України з екологічної кризи», «оздоровлення екології регіону», «поліпшення екологічної ситуації» тощо, - зосередженість на локальних екологічних проблемах (вирубка лісів, сміттєзвалища, забрудненість повітря та води та ін.) $€$ свідченням низького рівня екологічної компетентності, тобто відсутності цілісного бачення щодо необхідних змін в екологічній політиці та екологічному законодавстві України, - як зазначає голова правління ресурсно-аналітичного центру «Суспільство і довкілля» Н. Андрусевич «Велике здивування викликає той факт, що політичні партії чи кандидати, що декларують демократичні принципи та пропагують європейські стандарти, залишають питання довкілля поза увагою, хоча в демократичних країнах питання охорони довкілля займають достатньо пріоритетне значення», на підтвердження, наводить аналітичні данні: «було проаналізовано 3080 програм кандидатів. Із загальної кількості програм, 1985 не містять жодної згадки про екологічні питання, що становить 64,4\%. Лище 73 програми мають досить трунтовні положення щэодо питань охорони довкілля $(2,4 \%)$. Решта, 33,3\% програм хоча і мають згадку про довкілля, проте такі положення є часто декларативними і формальними» (Resursno-analitychnyi tsentr «Suspilstvo i dovkillia», 2012).

Слід відзначити, Україна має позитивний законодавчий досвід у вирішенні екологічних проблем, так головним стратегічним документом у сфері охорони довкілля $є$ - Закон України «Про основні засади (стратегію) державної екологічної політики України на період до 2030 року», в якому визначається низка стратегічних цілей: 1) підвищення рівня екологічної свідомості; 2) поліпшення екологічної ситуації та підвищення рівня 
екологічної безпеки; 3) досягнення безпечного для здоров’я людини стану навколишнього середовища; 4) інтеграція екологічної політики та вдосконалення системи інтегрованого екологічного управління; 5) припинення втрат біологічного та ландшафтного різноманіття i формування екологічної мережі; 6) забезпечення екологічно збалансованого природокористування; 7) удосконалення регіональної екологічної політики (Verkhovna Rada Ukrainy, 2019). Беззаперечно, Закон України №2697-III від 28 лютого 2019 - має наблизити Україну до загальносвітових та європейській стандартів екологічної політики сучасних держав, зокрема, адже в ньому прописані концептуальні засади, стратегічні цілі та завдання, етапи реалізації та контролю щодо - стратегії та програми охорони довкілля, екологічної експертизи, екологічного аудиту, екологічного маркування, екологічного страхування, технічного регулювання, стандартизації та обліку у сфері охорони довкілля та природокористування, освітнього та наукового забезпечення державної екологічної політики, контролю i санкцій, міжсекторального партнерства та міжгалузевої співпраці в питаннях охорони довкілля, податків, пільг, кредитних ставок, митних тарифів, норми амортизації для стимулювання екологобезпечного виробництва тощо (Verkhovna Rada Ukrainy, 2019), втім, - відкритим залишається питання практичної реалізації стратегії державної екологічної політики в українських реаліях.

По-третє, екологічний патерналізм українціів, попри визнання пріоритетності екологічних питань та усвідомлення особистої відповідальності за екологічне майбутне, українцям притаманний патерналістський підхід, прагнення перекладати відповідальності за вирішення екологічних проблем на владу, - означену антиномічність фіксує соціологія, так за даними дослідницького проекту «Екологічна свідомість українців. Факти і цифри»: «для 93\% українців охорона довкілля є важливою проблемою, а 87\% вважають, що можуть особисто відігравати роль у захисті українського довкілля» (Hromadska Synerhiia, 2018), в той же час, в рамках 
дослідження «Охорона довкілля та громадяни України» експертами було виявлено, що «Українці покладають відповідальність за вирішення проблем довкілля на владу (національна влада - 36,8\%, регіональна влада - 38,2\%, спільно з СС - 19,2\%), в той самий час, вражають індекси довіри/недовіри українців, щодо екологічних питань, так прогнозовано найвищі показники мають «науковці - 28,7\%, телебачення - 22,6\%, природоохоронні громадські організації - 21,9\%», найнижчі- «регіональна/місцева влада - 9,1\%, уряд/центральна влада - 4,6\%, політичні партї, щзо мають про екологічну позицію - 3,4\%» (Yevropeiskyi Soiuz ta Mizhnarodnyi fond «Vidrodzhennia», 2018), отже, - українці покладають відповідальність за вирішення екологічних проблем на владу, проте, на виборчих дільницях - маючи можливість делегувати до владних інституцій політичні сили, які прагнуть вирішення екологічних проблем та створення умов для екологічного майбутнього України, - не враховують даний аспект, так «45,2\% респондентів віднесли програмний пріоритет «захист довкілля» до індиферентних атрибутів», і лише «17,7\% респондентів «захист довкілля» до необхідних атрибутів у програмах політичних партій» (Yevropeiskyi Soiuz ta Mizhnarodnyi fond «Vidrodzhennia», 2018).

По-четверте, «рутинізація державної кризи», вочевидь, трансформаційні процеси українського демократичного державотворення, що супроводжуються системними кризовими явищами в політичній, економічній та соціальній сферах, зокрема, - суспільно-політична криза 90-х років, фінансово-економічні потрясіння, загострення соціальних проблем бідності, безробіття, міграції, зламні моменти суспільно-політичних подій «Помаранчевої Революції» (2003-2004) та «Революції Гідності» (2013-2014), військо-політичний конфлікт з РФ та інші надскладні українські реалії, призвели до того, що екологічне питання було витіснене на периферію політичного життя, а «виборчі симпатії» отримували політичні партії та кандидати, які апелювали саме до вирішення політичних, економічних та соціальних проблем, - як зазначив міністр екології та природних ресурсів 
України О. Семерак: «Екологія завжди була на останньому місці після економіки, охорони здоров'я та інших сфер життя» (Hromadska Synerhiia, 2018).

Очевидно, список перерахованих проблемних аспектів, що негативно впливають на інтеграцію екологічного питання в український політичний простір, - не є повним, проте, дозволяє зробити висновок, - ігнорування або зволікання 3 вирішення екологічних проблем $\epsilon$ безвідповідальним та недалекоглядним, - оскільки деструктивне антропогенно-техногенне навантаження вже призвело до критично стану з забрудненням повітря, води та грунтів в Україні, а якщо враховувати ще той факт, що «зміни клімату в Україні значною мірою $є$ синхронними 3 глобальними темпами» (Horyn, 2012) та вже помітні неозброєним оком кожному українцю, - настання масштабної «екологічної кризи» лише питання часу. Безумовно, відповідальність за екологічне майбутнє України - це спільна справа політиків і виборців, від екологічної компетентність яких значною мірою залежить перспектива створення ефективної державної політики в сфері екології. Слід наголосити, в сучасних умовах, коли екологічне питання набуває пріоритетності для «пересічного українця», натомість «старі політичні гравці» (тобто, політичні партії які перебувають при владі, продовжують маніпулювати та спекулювати на екологічних питаннях) не роблять реальних кроків щодо поліпшення екології в Україні - партії «зелених», попри минулі дивергенції та дискредитацію, мають шанс на політичний успіх у наступних виборчих компаніях.

Висновки і перспективи подальших досліджень. У підсумку, наведемо слова ексміністра екології та природних ресурсів України О. Семерака, - «світ змінюється, і захист довкілля, попередження змін клімату, стала економіка мають стати призмою, через яку влада повинна дивитися на всі інші сфери життя» (Hromadska Synerhiia, 2018), сподіваємось, ця теза стане політичним імперативом для української екологічної політики, а відтак, - запорукою екологічного майбутнього України. 


\section{ЛIТЕРАТУРА}

1. Бортник, Р., 2019. Не зазеленеет: Как политики будут использовать тему экологии для победы на парламентских выборах. [online] Доступно: https://112.ua/obshchestvo/ne-zazeleneet-kakpolitiki-budut-ispolzovat-temu-ekologii-dlyapobedy-v-parlamentskih-vyborah-492207.html [Дата звернення 21 Травень 2019].

2. Верховна Рада України, 2019. Закон України «Про основні засади (стратегію) державної екологічної політики України на період до 2030 року» від 28 лютого 2019 №2697-III, 2019. [online] Доступно: https://zakon.rada.gov.ua/laws/show/2697-19 [Дата звернення 17 Квітень 2019].

3. Горин, О., 2012. Нова кліматична ера: глобальне потепління може мати для України як негативні, так $i$ позитивні наслідки. [online] Доступно: https://tyzhden.ua/Society/55859 [Дата звернення 09 Квітунь 2019]

4. Громадська Синергія, 2018. 93\% украӥнців вважають охорону довкілля важливим питанням. [online] Доступно: https://www.civic-synergy.org.ua/news/93ukrayintsiv-vvazhayut-ohoronu-dovkillyavazhlyvym-pytannyam-sotsopytuvannya/ [Дата звернення 27 Червень 2019].

5. Свропейський Союз та Міжнародний фонд «Відродження», 2018. Охорона довкілля та громадяни України. Дослідження практик, цінностей та суджень 2018. [online] Доступно:

https://www.rac.org.ua/uploads/content/481/fil es/envportraitpollreport2018.pdf [Дата звернення 22 Червень 2019].

6. Коаліція неурядових громадських організацій, 2019. Порядок денний екологічної безпеки для політичних партій на парламентських виборах 2019 року. [online]

https://ecoagenda2019.org.ua/ Доступно: звернення 22 Липень 2019].

[Дата

7. Люленко, С., $2017 . \quad$ Громадські природоохоронні організації та напрями їх екологічної діяльності. Молодь $i$ ринок, 3(146), c. 62-66.

8. Ресурсно-аналітичний центр «Суспільство і довкілля», 2012. Екологічна складова передвиборних програм політичних партій та кандидатів у депутати на виборах до Верховної Ради України у 2012 роиі. [online] Доступно: https://www.rac.org.ua/uploads/content/130/fil

\section{REFERENCES}

1. Bortnik, R., 2019. Ne zazeleneet: Kak politiki budut ispolzovat temu ekologii dlya pobedy na parlamentskih vyborah. [online] Dostupno: https://112.ua/obshchestvo/nezazeleneet-kak-politiki-budut-ispolzovattemu-ekologii-dlya-pobedy-v-parlamentskihvyborah-492207.html [Data zvernennya 21 Traven 2019].

2. Verkhovna Rada Ukrainy, 2019. Zakon Ukrainy «Pro osnovni zasady (stratehiiu) derzhavnoi ekolohichnoi polityky Ukrainy na period do 2030 roku» vid 28 liutoho 2019 №2697-III, 2019. [online] Dostupno: https://zakon.rada.gov.ua/laws/show/2697-19 [Data zvernennia 17 Kviten 2019].

3. Horyn, O., 2012. Nova klimatychna era: hlobalne poteplinnia mozhe maty dlia Ukrainy yak nehatyvni, tak i pozytyvni naslidky. [online] Dostupno: https://tyzhden.ua/Society/55859 [Data zvernennia 09 Kviten 2019]

4. Hromadska Synerhiia, 2018. 93\% ukraintsiv vvazhaiut okhoronu dovkillia vazhlyvym pytanniam.. [online] Dostupno: https://www.civic-synergy.org.ua/news/93ukrayintsiv-vvazhayut-ohoronu-dovkillyavazhlyvym-pytannyam-sotsopytuvannya/ [Data zvernennia 27 Cherven 2019].

5. Yevropeiskyi Soiuz ta Mizhnarodnyi fond «Vidrodzhennia», 2018. Okhorona dovkillia ta hromadiany Ukrainy. Doslidzhennia praktyk, tsinnostei ta sudzhen 2018. [online] Dostupno:

https://www.rac.org.ua/uploads/content/481/fi les/envportraitpollreport2018.pdf [Data zvernennia 22 Cherven 2019].

6. Koalitsiia neuriadovykh hromadskykh orhanizatsii, 2019. Poriadok dennyi ekolohichnoi bezpeky dlia politychnykh partii na parlamentskykh vyborakh 2019 roku. [online]

Dostupno: https://ecoagenda2019.org.ua/

[Data zvernennia 22 Lypen 2019].

7. Liulenko, S., $2017 . \quad$ Hromadski pryrodookhoronni orhanizatsii ta napriamy yikh ekolohichnoi diialnosti. Molod i rynok, 3(146), s. 62-66.

8. Resursno-analitychnyi tsentr «Suspilstvo i dovkillia», 2012. Ekolohichna skladova peredvybornykh prohram politychnykh partii ta kandydativ u deputaty na vyborakh do Verkhovnoi Rady Ukrainy u 2012 rotsi. [online] Dostupno: https://www.rac.org.ua/uploads/content/130/fi 
es/environmentinelectionsparliament2012relea sed.pdf [Дата звернення 22 Червень 2019].

9. Толстоухов, А., $2006 . \quad$ Еко-майбутнє починається 3 «Еко $+25 \%$ \% [online] (Останнє оновлення 27 Січень 2006) Доступно:

https://dt.ua/ENVIRONMENT/ekomaybutne_pochinaetsya_z_eko25.html [Дата звернення 10 Травень 2019].

10. Datatowel.in.ua, 2019. Парламентські вибори в Україні 1998. [online] Доступно: https://datatowel.in.ua/elections/parliamentary 1998 [Дата звернення 30 Квітень 2019]. les/environmentinelectionsparliament2012rel eased.pdf [Data zvernennia 22 Cherven 2019].

9. Tolstoukhov, A., 2006. Eko-maibutnie pochynaietsia $z \quad$ «Eko+25\%». [online] (Ostannie onovlennia 27 Sichen 2006) Dostupno: https://dt.ua/ENVIRONMENT/ekomaybutne_pochinaetsya_z_eko25.html [Data zvernennia 10 Traven 2019].

10. Datatowel.in.ua, 2019. Parlamentski vybory v Ukraini 1998. [online] Dostupno: https://datatowel.in.ua/elections/parliamentar y1998 [Data zvernennia 30 Kviten 2019].

\section{Інформація про автора}

Калюжна Юлія Іванівна - кандидат політичних наук, викладач кафедри політології, соціології і культурології Харківського національного педагогічного університету імені Г.С. Сковороди; e-mail: kaliuzhna.yulia@gmail.com; ORCID: https://orcid.org/0000-00027344-410X.

Стаття надійшла до редакції: 27.11.2019 р. $\quad$ Прийнята до друку: 13.12.2019 p. 